\title{
THE EU COURT OF JUSTICE CLARIFIES THE ROLE OF THE FULL-FUNCTION CRITERION IN THE INTERACTION BETWEEN ARTICLE 3(1)(B) AND 3(4) OF THE EU MERGER REGULATION
}

\author{
VASILIKI FASOULA*
}

\begin{abstract}
Case note: C-248/16 Austria Asphalt GmbH \& Co OG v Bundeskartellanwalt, Judgment of the Court of Justice of the European Union of the 7th of September 2017. Joint venture is a common business strategy that provides companies with benefits in scale economies, R\&D, operational efficiencies and synergies. Joint ventures can be potentially harmful for the state of free competition in a market if they coordinate with their parent companies or if their operation can restrict access to the market for other competitors. Within the Internal Market, joint ventures fall under the scrutiny of two pieces of competition legislation in a non-cumulative way: the EU antitrust provisions and the EU Merger Regulation (EUMR) under Article 3(1)(b) and 3(4). Before the Austria Asphaltpreliminary ruling, the Commission, despite its ambiguous decisional practice, considered those two paragraphs to constitute two different jurisdictional criteria applying to two different types of notifiable transactions. In Austria Asphalt the CJEU examined the correlation of those two paragraphs. It interpreted Article 3(4) as a restriction of Article 3(1)(b) by considering that the full-function criterion set by Article 3(4) should apply to all concentrative joint ventures: those newly created by a transaction as well as to those resulting from a change in the control of an existing company. In practice, the CJEU's view limits the one-stop shop principle of the EUMR in favour of national competition authorities.
\end{abstract}

\section{INTRODUCTION}

By this preliminary ruling, the Court of Justice of the European Union (CJEU) provides some clarity on the extent of the scope of implementation of the EUMR ${ }^{1}$ to joint ventures. The incoherence in the European Commission's (the Commission) decisional practice regarding joint ventures falling under the scope of the EUMR had led to a division of the legal scholarship and to a certain degree of legal uncertainty on the interaction between the jurisdictional criteria set out in Article 3(1)(b) and 3(4) of the EUMR. ${ }^{2}$ The question asked by the referring court was whether a change from sole control to joint control over an

\footnotetext{
* PhD candidate in Competition Law, University Paris II Panthéon-Assas, France, ATER in Private Law, University Paris Nanterre, France. The author would like to thank the anonymous reviewer(s) for the insightful comments that improved the clarity and quality of the paper.

${ }^{1}$ Council Regulation (EC) 139/2004 of 20 January 2004 on the control of concentrations between undertakings [2004] OJ L24/1.

${ }^{2}$ According to Article 3(1)(b), a notifiable concentration under the EUMR is any transaction where a lasting change of control arises from the acquisition of direct or indirect control of the whole or parts of one or more other undertakings. According to Article 3(4), the creation of a joint venture performing on a lasting basis all the functions of an autonomous economic entity constitutes a concentration within the meaning of Article $3(1)(b)$.
} 
existing undertaking constitutes a notifiable concentration only where the resulting joint venture performs on a lasting basis all the functions of an autonomous economic entity, ie a full function joint venture, post-transaction. The CJEU must therefore determine the role of Article 3(4) in the structure of the EUMR. Is it meant to be interpreted as a limit to the scope of application of Article 3(1)(b) of the EUMR to joint ventures or to establish an additional notifiable transaction next to those under article $3(1)(b)$ if a full-function joint venture is created post-transaction?

The Court's answer to the referred question was that a change from sole to joint control over an existing undertaking was a notifiable concentration under the EUMR only if the joint venture created by such a transaction performs all the functions of an autonomous economic entity. This means in practice that a high number of transactions may no longer fall under the scope of the ex ante control established by the EUMR.

\section{FACTS OF THE CASE}

The events leading up to a request for this preliminary ruling concern the evolution of a production joint venture in the Austrian city of Mürzzuschlag. Austria Asphalt GmbH \& Co OG (AA) is an indirect subsidiary of Strabag SE while Teerag Asdag (TA) belongs to the Porr Group. Both companies are international construction groups operating mainly in the field of road construction. The Mürzzuschlag asphalt mixing plant produces asphalt used in road construction and supplies it almost exclusively to TA which is its sole owner. On 3 August 2016, the two above mentioned companies notified a transaction to the Austrian Federal Competition Authority (Bundeswettbewerbsbehörde) by which AA would acquire $50 \%$ of the shares of the asphalt mixing plant, i.e. the target undertaking, previously owned solely by TA. According to the referring court, the transaction should not be viewed as a full-function joint venture because the joint venture created would supply the asphalt produced in the plant almost exclusively to both its parents companies. Under the Austrian merger control provisions, the creation of a non-full-function joint venture may fall under the scope of national law, ie Kartellgesetr, if certain criteria are met, therefore, the transaction would constitute a notifiable concentration before the competent authority of Austria.

According to the procedure of national law, the Austrian Federal Cartel Prosecutor (Bundeskartellanwalt), lodged with the Higher Regional Court in Vienna (Oberlandesgerichtshof Wien) acting as cartel court, an application for review under Paragraph 11(1) of the Kartellgesetz: According to the cartel court, the notified transaction constituted a concentration with an EU dimension and therefore it should fall under the scope of the EUMR. AA lodged an appeal before the Austrian Supreme Court (Oberster Gerichtshof) arguing that the transaction should be treated as a concentration requiring notification under the scope of Paragraphs 7 and 9 of national competition law, ie Kartellgeset: The referring court noted that there was no clarification in the case law on the interpretation of Article 3(4) of the EUMR and its correlation with Article 3(1) of the EUMR, nor in the Jurisdictional Notice ${ }^{3}$ or the Commission's decisional practice. Therefore, under Article 267 of the Treaty on the Functioning of the European Union (TFEU) the Austrian Supreme Court submitted a

\footnotetext{
${ }^{3}$ Commission Consolidated Jurisdictional Notice under Council Regulation (EC) 139/2004 on the control of concentrations between undertakings [2008] OJ C95/1.
} 
request for a preliminary ruling asking the following: must Article 3(1)(b) and 3(4) of the EUMR be interpreted as meaning that a move from sole control to joint control of an existing undertaking, in circumstances where the undertaking previously having sole control becomes an undertaking exercising joint control, constitutes a concentration only where the undertaking, the control of which has changed, has on a lasting basis all the functions of an autonomous economic entity?

\section{THE OPINION OF ADVOCATE GENERAL KOKOTT}

In her opinion, ${ }^{4}$ Advocate General (AG) Kokott states that the actual wording of Article 3(1)(b) and 3(4) of the EUMR does not provide for a clear picture on the joint ventures that fall under the scope of EUMR. Therefore, many interpretations are plausible, like the ones argued by the parties during the proceedings. On the one hand, AA argued that only fullfunction joint ventures were subject to the EUMR based on Article 3(4). On the other hand, the Commission argued that a change in control, from sole to joint, of an existing undertaking should at all times be subject to the EUMR, even if the target undertaking was not a full-function one based on Article 3(1)(b). The Commission also emphasized that the application of the full-function criterion, in cases of change in the control, could create an 'enforcement gap' in the EU merger control regime. Interesting enough, the Commission had argued for the opposite interpretation on the same case, when AA consulted the Commission and received a non-binding comfort letter from the Commission's Directorate General for Competition (DG Competition) that the transaction did not appear to constitute a concentration falling under the scope of Article 3 of the EUMR. ${ }^{5}$ While the comfort letter came with the disclaimer that the view expressed in it is an opinion of the DG Competition and does not bind the Commission as an EU institution, the AG criticised the incoherence within the Commission's services in the matter of the scrutiny of joint ventures under the EUMR.

Since the textual interpretation could not clarify Article 3 of the EUMR, the AG proceeded to a teleological approach of the general scheme as well as the drafting history of the EUMR. According to the AG, the provision of Article 3(4) read alongside with recital 20 of the EUMR does not distinguish between newly created joint ventures and those that result from a conversion of an existing company into a joint venture. Instead, it lays down the fullfunction criterion as being applicable to all joint ventures, irrespective of whether the joint venture concerned is a newly created one or an existing company converted to a joint venture. ${ }^{6}$ The AG continues by stating that recitals 8 and 20 aim at bringing under EU merger control those transactions that may cause significant structural changes in the internal market. In the AG's opinion, an undertaking with no autonomous presence in the market cannot effect its structure such as to justify an EU merger control scrutiny. According to the AG, if a transaction gives rise to a joint venture which is not full-function:

\footnotetext{
${ }^{4}$ Case C-248/16 Austria Asphalt GmbH \& Co OG v Bundeskartellanwalt [2017] ECLI:EU:C:2017:322, Opinion of AG Kokott.

5 ibid pt 14.

6 ibid pt 28.
} 
[T] here will at most be a need to deal with any coordination by the two parent companies of the behaviour in which they engage on the market as part of their collaboration within the joint venture. Such coordination of market behaviour, even though it may be entirely relevant from the point of view of Articles 101 and 102 TFEU, is an issue to be considered not under the EU merger control regime but under Regulation $1 / 2003^{7}$. 8

Further, the AG strongly disagreed with the Commission's view during the hearing of the case that the application of the full-function criterion to all the joint ventures under the EUMR - which was according to her, the intention of the legislator of Regulation 1310/979 from which originated Article 3(4) of the EUMR- would create a gap in the effective enforcement of the EUMR. The AG did not comment on the effect to the market structure by a possible disappearance of a joint venture as being a matter subject to the EUMR. ${ }^{10}$

\section{JUDGMENT OF THE COURT}

The Court held that the wording alone of Article 3 of the EUMR was not clear enough to determine whether a transaction, as the one of the case, involving a change of sole to joint control by two shareholders, over an existing undertaking, is notifiable to the Commission only if the joint venture resulting is a full-function one. According to the Court, such a transaction would on the one hand, satisfy the criterion of a change of control on a lasting basis under Article 3(1)(b), but on the other hand, it is not clear whether it could be regarded as a creation of a joint venture under Article 3(4) because of the pre-existence of the joint venture as an undertaking prior to the transaction.

Since the textual interpretation cannot offer clarity on the legal matter at hand, the Court proceeds to the teleological interpretation of legal provisions by analysing the purpose and the general scheme of the EUMR. In order to specify the objective of the EUMR, the Court is referring to the combined reading of Recitals $5,{ }^{11} 6,{ }^{12} 8,{ }^{13}$ and $20^{14}$ as well as to Article

\footnotetext{
${ }^{7}$ Council Regulation (EC) 1/2003 of 16 December 2002 on the implementation of the rules on competition laid down in Articles 81 and 82 of the Treaty [2003] OJ L1/1.

${ }^{8}$ Opinion of AG Kokott (n 4), pt 38.

${ }^{9}$ Council Regulation (EC) 1310/97 of 30 June 1997 amending Regulation (EEC) 4064/89 on the control of concentrations between undertakings [1997] OJ L180/1.

${ }^{10}$ Opinion of AG Kokott (n 4), pts 46-47.

${ }^{11}$ Recital 5 of the EUMR stipulates that 'it should be ensured that the process of reorganisation does not result in lasting damage to competition; Community law must therefore include provisions governing those concentrations which may significantly impede effective competition in the common market or in a substantial part of it'.

${ }_{12}$ Recital 6 of the EUMR stipulates that the aim of the Regulation is 'to permit effective control of all concentrations in terms of their effect on the structure of competition in the Community and to be the only instrument applicable to such concentrations (...)'.

${ }^{13}$ Recital 8 of the EUMR stipulates that 'the provisions to be adopted in this Regulation should apply to significant structural changes, the impact of which on the market goes beyond the national borders of any one Member State. Such concentrations should, as a general rule, be reviewed exclusively at Community level, in application of a "one-stop shop" system and in compliance with the principle of subsidiarity. Concentrations not covered by this Regulation come, in principle, within the jurisdiction of the Member States'.

${ }^{14}$ Recital 20 of the EUMR stipulates that 'it is expedient to define the concept of concentration in such a manner as to cover operations bringing about a lasting change in the control of the undertakings concerned and therefore in the structure of the market. It is therefore appropriate to include, within the scope of this
} 
2(1) and 2(4) of the EUMR on the appraisal of concentrations. The purpose of the EUMR is to ensure that the reorganisation of undertakings does not result in lasting damages to competition in the European Union therefore this regulation should apply to significant structural changes on the market the impact of which goes beyond the national borders of any one Member State. ${ }^{15}$ The transactions that fall under the scope of the EUMR are, according to the Court, the ones that bring about a lasting change in the control of the undertakings and therefore in the structure of the market. Thus, as regards joint ventures, 'these must be included within the ambit of the regulation if they perform on a lasting basis all the functions of an autonomous economic entity'. ${ }^{16}$

Following point 28 of the Opinion of the AG, the CJEU states that a distinction between the creation of a new undertaking after the transaction and the change of control over an existing undertaking prior to the transaction is not necessary. The reason being that in both cases the potential effects of the transaction on the structure of the market depend 'on the actual emergence of a joint venture into the market, that is to say, of an undertaking performing on a lasting basis all the functions of an autonomous economic entity'. ${ }^{17} \mathrm{~A}$ converse interpretation of Article 3 of the EUMR would lead, according to the Court's ruling, to an unjustified difference in treatment between the creation of a new undertaking which would be treated as a concentration only if the full-function criterion was fulfilled, and a change of control of an existing undertaking, which would be covered by the concept of concentration irrespective of whether that undertaking would be active as an autonomous economic entity post-transaction. ${ }^{18}$

The Court states that its interpretation of Article 3 is consistent with the general scheme of the EUMR. The latter alongside Regulation 1/2003 on the implementation of Articles 101 and 102 TFEU, form a 'legislative whole' establishing a system of control ensuring that competition is not distorted in the internal market of the European Union. ${ }^{19}$ Pursuant to Article 21(1) of the EUMR, the latter applies to concentrations within the meaning of Article 3, whereas transactions that are covered by the concept of concentration but are nevertheless capable of leading to coordination between undertakings in breach of Article 101 TFEU are subject to Regulation $1 / 2003 .{ }^{20}$ In that view, treating a change from sole to joint control over an existing undertaking as a notifiable concentration even if the full-function criterion was not fulfilled, as this was argued by the Commission, would be inconsistent with Article 21 of the EUMR, because that would extend the scope of the Merger Regulation's preventative control, and, at the same time, limit the scope of Regulation $1 / 2003 .^{21}$

The CJEU's conclusion is that Article 3 of the EUMR must be interpreted as meaning that a concentration is deemed to arise upon a change in the form of an existing undertaking

Regulation, all joint ventures performing on a lasting basis all the functions of an autonomous economic entity $[\ldots]$ '.

${ }^{15}$ Case C-248/16 Austria Asphalt GmbH \& Co OG v Bundeskartellanwalt [2017] ECLI:EU:C:2017:643, pt 21.

16 ibid pt 22.

17 ibid pt 24.

18 ibid pt 27.

19 ibid pt 31.

20 ibid pt 33.

21 ibid pt 34. 
which, previously exclusive, becomes joint, only if the joint venture created by such a transaction performs on a lasting basis all the functions of an autonomous economic entity.

\section{COMMENTS}

The concept of joint venture is essentially an economic one without a clear legal definition in the European legal order. Joint ventures are subject to contract law provisions, corporate law as well as competition law provisions. In the present ruling, the CJEU makes a clarification on the criteria that must be fulfilled in order for a joint venture to fall under the scrutiny of the EUMR. The term of joint venture describes, in general, a contractual agreement between two or more autonomous undertakings willing to cooperate in order to achieve a determined economic objective during the course of a reasonable period of time or for a time frame that may not be specifically determined in the contract. ${ }^{22}$ All parties are able to exercise considerable control or influence over the legal form chosen for the joint venture. ${ }^{23}$ Largely used in the practice of US firms, the American antitrust legal doctrine and practice supported the compatibility of these contractual agreements with antitrust rules due to the efficiency effects they were producing but also recognised that they could have some potentially anticompetitive effects similar to mergers and board of directors' interlocks. ${ }^{24}$ Joint ventures are viewed as 'an important and distinct category for antitrust analysis because of their potential to bring about an efficiency-enhancing integration of economic activity. Many different forms of economic integration may be effected by joint ventures and each may enhance efficiency in more than one way. ${ }^{25}$

In EU law, the assessment of joint ventures falls under two different bodies of EU competition law in a non-cumulative way: a joint venture may fall either under the scope of the antitrust provisions as laid down in Articles 101 and 102 TFEU and enforced by Regulation 1/2003 or under the scope of merger control provisions as laid down in the EUMR. This normative distortion in the assessment of joint ventures under EU competition law prohibited the development of a unitary competition analysis of joint ventures in the European market. The enforcement of EU antitrust rules was established almost at the beginning of the economic integration of the European market by Regulation $17 .{ }^{26}$ Hence, the cooperation agreements between undertakings in connection with the establishment and functioning of joint ventures were falling under the exclusive scrutiny of Article 85 EEC Treaty, now Article 101 TFEU. In its early decisional practice under Regulation 17, the Commission forwarded the thesis that EU antitrust scrutiny was necessary when the joint ventures would act as actual or potential competitors to their parent undertakings with the

\footnotetext{
22 Antony Woolich, 'Joint Ventures in the European Union' in Martin Mankabady (ed), Joint ventures in Europe (3rd edn, Tottel Publishing, 2008); Laurent Deis, 'Les contrats de coopération inter-entreprises' (PhD thesis in Law, University of Paris II 2002).

${ }^{23}$ Wolf Ronald, The complete guide to international joint ventures with sample clauses and contracts (3rd edn, Kluwer Law International 2011).

${ }^{24}$ Jeffrey Pfeffer, Phillip Nowak, 'Patterns of Joint Venture activity: Implications for Antitrust Policy' (1976) 21 Antitrust Bulletin 315.

${ }^{25}$ Werden Gregory, 'Antitrust Analysis of Joint Ventures: An Overview' (1998) ALJ 702; Ian Hewitt, Joint Ventures, (2 ${ }^{\text {nd }}$ edn, Sweet \& Maxwell 2001).

${ }^{26}$ Council Regulation (EEC) No 17 First Regulation implementing Articles 85 and 86 of the Treaty (at present Articles 101 and 102 TFEU) [1962] OJ 13/1.
} 
exception of two types of situations that were falling outside the scope of Article 85 EEC Treaty: 1) the cases where the parent undertakings had transferred all their assets to one or multiple joint ventures while maintaining their independence only for the purpose of monitoring the joint ventures activities; 2) the cases where the parent undertakings would transfer a significant part of their assets to a joint venture and then they would withdraw entirely from the market where the joint venture was active. These latter cases where qualified by the Commission as partial concentrations. ${ }^{27}$ Until the adoption of the first EUMR in $1989,{ }^{28}$ the above mentioned two types of joint ventures were not subject to any particular form of competition scrutiny due to the absence of a legal framework on direct control of concentrations. $^{29}$

The first EUMR tried to cover this legal lacuna in joint venture competition scrutiny by stipulating in its Article 3(2) that only joint ventures that performed on a lasting basis all the functions of an autonomous economic entity and that did not give rise to coordination of the competitive behaviour of the parties amongst themselves or between them and the joint venture at stake would fall under the scope of the EUMR. This caused a qualification division between joint ventures viewed as a concentrative entity, subject to the EUMR, and those viewed as a cooperative entity, subject to the EU antitrust provisions. The distinction between concentrative and cooperative joint ventures that is still in force today, served as a jurisdictional factor assigning joint ventures to different substantive and procedural systems to the detriment of predictability of the outcomes of jurisdictional rules. That distinction was criticised as being 'deeply flowed' ${ }^{30}$ from an economic perspective because it assigned operations with similar effects on market structure to different substantive and procedural systems. The legal criteria for the qualification of joint ventures, under both bodies of EU competition law, which were delineated by the Commission for the first time in its 1990 Interpretative Notice on the distinction between concentrative and cooperative operations ${ }^{31}$ were subject to an evolutionary interpretation. The 1994 Interpretative Notice between concentrative and cooperative joint ventures ${ }^{32}$ broadened the scope of qualification of joint ventures as concentrative entities subject to the EUMR, as did the amendment of EUMR by Regulation $1310 / 97 .^{33}$

The objective of the Commission's White Paper on Modernisation of EC Antitrust $\mathrm{Law}^{34}$ was to decentralise the application of EU competition law by national authorities and courts leading up to a convergence of national law and EU law and to a consistent and uniform application of antitrust law within the European Market. Concerning the decentralisation of the exemption mechanism of now Article 101 (3) TFEU, the Commission

\footnotetext{
${ }^{27}$ Karen Banks, 'Mergers and Partial Mergers' in Barry Hawk (ed), Annual Proceedings of the Fordham Corporate Law Institute: North American and Common Market Antitrust and Trade Laws 1987 (M. Bender 1988).

${ }^{28}$ Council Regulation (EEC) No 4064/89 on the control of concentrations between undertakings [1989] OJ L395/1.

${ }^{29}$ Luis Silva Morais, Joint Ventures and EU Competition Law (Hart, 2013).

30 Barry Hawk, 'Joint Ventures under EEC Law' [1991] Fordham Int'l LJ 303.

${ }^{31}$ Interpretative Notice on the distinction between concentrative and cooperative operations [1989] OJ L395/1.

32 Interpretative Notice on the distinction between concentrative and cooperative joint ventures [1994] OJ C385/1.

33 Council Regulation (EC) No 1310/97 amending Regulation (EEC) No 4064/89 on the control of concentrations between undertakings [1994] OJ L180/1.

34 White Paper on Modernization of the rules implementing Articles 81 and 82 of the EC Treaty [1999] OJ C132/1.
} 
argued that the requirement of prior central authorisation should be maintained for partialfunction production joint ventures to which a certain minimum level of assets was to be contributed. The reason being that these transactions required substantial investment and profound operational integration which would be difficult to unravel once the transaction was concluded. ${ }^{35}$ The Commission argued for a system of compulsory prior notification for these transactions. In the Commission's view.

$[T]$ he procedures established by the Merger Regulation allow rapid and effective prior control. The Commission accordingly envisages extending the scope of that Regulation to include partial-function joint production ventures, which would be subjected both to the dominance test, under Article 2(3) of the Regulation (i.e. Regulation 4064/89 at the time), and to the Article 85 test, under Article 2(4)'. ${ }^{36}$

Two years after the White Paper on the modernisation of EU antitrust provisions, the Commission did not include any specification on partial-function production joint ventures constituting a concentration under the scope of the EUMR in its Green Paper on the Reform of the Merger Control Regulation. ${ }^{37}$ Finally, the EUMR that resulted after that process, adopted the ambiguous wording of Article 3(1)(b) and 3(4) that the Austria Asphalt ruling comes to clarify.

In Austria Asphalt, the Court equates the 'creation of a joint venture' laid down in Article 3(4) with a 'transaction as a result of which an undertaking controlled jointly by at least two other undertakings emerges in the market'. ${ }^{38}$ Hence, the creation of a joint venture includes the acquisition of joint control of an existing undertaking and the formation of a new undertaking by two or more parties. This means that the CJEU interprets Article 3(4) as a restriction of Article 3(1)(b) since it applies the full-function criterion not only to transactions falling under the scope of Article 3(4) but also to changes over existing undertakings that fall under the scope of Article 3(1)(b). This expansion of the full-function criterion to also Article 3(1)(b) essentially adds a criterion that the legal text applies only to Article 3(4). One may, in that case, wonder of the choice of the legislator to separate a single concept -according to the Court's ruling- in two different paragraphs of the same piece of legislation, ie the EUMR.

The Commission's position during the proceedings, that the joint control of Article 3(1)(b) and the full-function criterion of Article 3(4) apply to different types of notifiable transactions was consistent with the views laid down by the Commission in its soft law instruments providing guidance as to jurisdictional issues under the EUMR, ie the Notice on the concept of full-function joint ventures ${ }^{39}$ and its corresponding section of the Consolidated Jurisdictional Notice ${ }^{40}$ which replaced it. The Jurisdictional Notice stipulates that ' $[\ldots]$ a transaction involving several undertakings acquiring joint control of another

\footnotetext{
35 ibid paras 79-80; Lennart Ritter, David Braun, European Competition Law: A Practitioner's Guide (3 ${ }^{\text {rd }}$ edn, Kluwer Law International 2005).

36 ibid para 81.

${ }^{37}$ Green Paper on the Review of the Council Regulation (EEC) n 4064/89, COM (2001) 745.

${ }^{38}$ Case C-248/16 Austria Asphalt GmbH \& Co OG v Bundeskartellanwalt [2017] ECLI:EU:C:2017:643, pt 28.

${ }^{39}$ Commission Notice on the concept of full-function joint ventures [1998] OJ C66/5.

${ }^{40}$ Commission Consolidated Jurisdictional Notice under Council Regulation (EC) 139/2004 on the control of concentrations between undertakings [2008] OJ C95/1.
} 
undertaking or parts of another undertaking, fulfilling the criteria set out in paragraph 24, from third parties will constitute a concentration according to Article 3(1) without it being necessary to consider the full-functionality criterion'. ${ }^{41}$ Also, as far as article 3(4) of the EUMR is concerned it 'provides in addition that the creation of a joint venture performing on a lasting basis all the functions of an autonomous economic entity (so called full-function joint ventures) shall constitute a concentration within the meaning of the Merger Regulation $[\ldots]{ }^{42}$ The joint venture is 'not full-function if it only takes over one specific function within the parent companies' business activities without its own access or presence on the market'. ${ }^{43}$ For a joint venture to be viewed as an independent economic actor in the market place for a significant amount of time, the legal scholarship recognises that, in general terms, the joint venture must be self-sufficient in the matter of financial, material and human resources and be able to design its own commercial strategy. ${ }^{44}$

In the Commission's decisional practice, the elements of the full-functionality criterion have been assessed in a variety of ways. ${ }^{45}$ For example, in $R S B /$ Tenex ${ }^{46}$ the Commission found the EUMR inapplicable in the transaction because of lack of the fullfunction character for the reason that in its shareholders' agreement it was written that the main purpose of the joint venture was to provide services to one of its parent undertakings. In Marsk Data/Den Danske Bank ${ }^{47}$ the transaction was assessed as a concentration under the EUMR and the joint venture had full functionality because $15 \%$ of its sales were destined to third parties in the first year of its creation with a gradual rise until $65 \%$ by its third year. In La Poste/Swiss Post ${ }^{8}$ the Commission approved the concentration with commitments and it assessed the joint venture to have full-functionality because of its sales that were destined to, mostly, third parties despite the fact it would have to purchase supplies almost exclusively from its parents. In the matter of resources of a joint venture, the Commission in $K L M /$ Alitalia $^{49}$ did not require that the joint venture be the owner of such resources but to have access to them by its parents in order to carry out its business plan and to operate in the market.

Although the Commission's position in the proceedings before the CJEU was that Article 3(1)(b) and Article 3(4) should constitute two different jurisdictional criteria for a transaction to be assessed under the EUMR, its decisional practice has not been, in the past, very clear about that distinction. ${ }^{50}$ In Eni/Acegasaps/JV ${ }^{51}$ the Commission stated in paragraph 9 that:

\footnotetext{
41 ibid para 91.

42 ibid para 92.

43 ibid para 95.

${ }^{44}$ Kadir Baş, The Substantive Appraisal of Joint Ventures under the EU Merger Control Regime (Wolters Kluwer 2015); Michel Glais, Économie de l'entreprise et des marchés, (Economica 2017).

${ }^{45}$ Maher Dabbah, EC and UK Competition Law: Commentary, Cases and Materials, (Cambridge University Press 2004).

46 RSB/TENEX/Fuel Logistic (Case No IV/M.904) [1997] OJ C168/5.

${ }^{47}$ Marsk Data/Den Danske Bank-DM Data (Case No IV/M.1005) [1998] OJ C46/4.

${ }^{48}$ La Poste/Swiss Post/JV (Case No COMP/M.6503) [2012] OJ C94/1.

${ }^{49} \mathrm{KL} M /$ Alitalia (Case M/JV-19) [1999] OJ C184/1.

${ }^{50}$ Francesco Russo et al., European Commission Decisions on Competition: Economic Perspectives on Landmark. Antitrust and Merger Cases (Cambridge University Press 2010).

${ }^{51}$ ENI/Acegasaps/JV (COMP/M.6068) [2011] OJ C144/6, paras 10-11.
} 
[F]or the purpose of the present case there is no need to assess the full-functionality nature of the Target as the envisaged transaction consists of the acquisition of joint control over a pre-existing business with a market presence consistent with Paragraph 91 of the Commission Jurisdictional Notice'.

While at the following paragraph it cited that it follows from the foregoing, that the operation consists in a concentration within the meaning of Article 3(4) of the Merger Regulation'. ${ }^{52}$ In Volvo/Henleys ${ }^{53}$ the notified transaction concerned a joint control of a holding company. The Commission cited in its paragraph 12 that the undertaking resulting from the transaction 'will constitute a concentrative, full-function, autonomous joint venture in the terms of the Merger regulation'. In Soulè s4 the transaction concerned an acquisition of joint control by two undertakings of an existing third one 'within the meaning of Article 3(1)(b)' that according to the Commission in paragraphs 8-9 would now 'constitute a full function joint venture within the meaning of Article 3(4) (..) Therefore, the operation is a concentration within the meaning of Article 3 of the EC Merger Regulation'. In Laucoop ${ }^{5}$ the Commission also applied the full-function criterion to Article 3(1)(b) concerning the acquisition of a joint control of an existing undertaking already in operation in the market. It stated in paragraph 11 that:

' $[\mathrm{H}]$ aving regard to the above, the joint venture will perform on a lasting basis all the activities of an autonomous economic entity. NYK's acquisition of joint control of LauCool therefore constitutes a concentration within the meaning of Article 3(1)(b) of Council Regulation (EC) No 139/2004'.

In the aftermath of Austria Asphalt ruling, there is no need for the Commission to make a distinction between Article 3(1)(b) and (4) of the EUMR in its decisions since the CJEU imposes the fulfilment of the full-function criterion to transactions falling under both cases. In fact, since 2018, in decisions concerning joint ventures, the Commission has adopted the wording that the notifying parties have acquired 'within the meaning of Article 3(1)(b) and 3(4) of the EUMR' the joint control of the undertaking or of the newly founded joint venture or just of the joint venture. ${ }^{56}$ Also, following the Court's interpretation of Article 3 of the EUMR, the 'one-stop shop' principle of EU merger control may in fact be limited. Joint ventures that may potentially effect the structure of competition on the market place - either by their emergence on the market or by their disappearance from it, which the CJEU considered the latter to be irrelevant - may not fulfil the thresholds set by the EUMR, thus ending up being caught by national merger control provisions and falling under the scrutiny of national competition authorities. If the transactions may not be qualified as concentrations under national merger control, they may fall under the scope of EU and national antitrust law if the criteria of these provisions are fulfilled.

\footnotetext{
52 Ibid para 10.

53 Volvo/Henlys (Case No IV/M.593) [1995] OJ C132/2.

54 Toepfer/InVivo/Soulès (Case No COMP/M.4042) [2005] OJ C68/20.

55 NYK/Lauritzen Cool/LauCool JV (Case No COMP/M.3798) [2005] OJ C178/6.

${ }^{56}$ For instance, Elg Haniel/Iberinox/JV (Case No M.8606) [2018] OJ C100/2, Oney/4Finance/JV (Case No M.8726) [2018] OJ C82/1, Diamond Transmission Corporation/Infrared Capital Partners/JV (Case No M.8728) [2018] OJ C107/2, Amtrust/Madison Dearborn Partners/Mayfield Holdings JV (Case No M.8737) [2018] OJ C29/1, Repsol/KIA/JV (Case No M.8783) [2018] OJ C73/1, GE/Rosneft/JV (Case No M.8820) [2018] OJ C165/1.
} 
In the matter of scrutiny of concentrative joint ventures, there is no harmonisation amongst the EU Member States. ${ }^{57}$ For instance, some national legislations have a broader definition of what constitutes a concentration by including the acquisition of minority shareholdings in the concept of joint control like Austria, Germany and the UK while in France, the Netherlands and Spain the full-function of a joint venture, newly created by the transaction or by a change in the control of a pre-existing undertaking, is a prerequisite for notification. ${ }^{58}$ Most of the national competition authorities follow the Jurisdictional Notice as a mean to provide guidance to a consistent application of competition law within the European Market. Since the qualification of a joint venture as a full-function undertaking requires a more 'forward-looking assessment ${ }^{59}$ on the basis of specific criteria set out in the Jurisdictional Notice, it remains to be seen if after Austria Asphalt, the Commission will reassess the concept of full-functionality as laid down in paragraphs 91-109 of the Jurisdictional Notice in order to reinforce legal security of market operators and provide guidance to the national competition authorities for a more convergent application of national merger control provisions on joint ventures.

${ }^{57}$ Richard Whish, David Bailey, Competition Law (8th edn, Oxford University Press 2015).

${ }^{58}$ Maher Dabbah, K.P.E. Lasok, Merger Control Worldwide: Volume I and Volume II (2 ${ }^{\text {nd }}$ edn, Cambridge University Press 2012).

59 Johannes Lübking, ‘Commission adopts Jurisdictional Notice under the Merger Regulation' (2007) Competition Policy Newsletter 3, 4. 